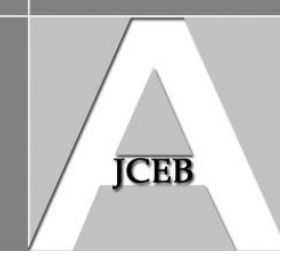

\title{
A Comparative Approach to Determining the Growth of Productivity of the New Zealand Construction Industry
}

\author{
Malcolm Abbott, (Swinburn University of Technology, Australia) \\ Chris Carson, (Unitech Institute of Technology, New Zealand)
}

\begin{abstract}
In recent years there has been increasing interest in the productivity and efficiency of the construction industry in New Zealand. In part this interest has manifested itself in the increased use of numerous statistical techniques to determine the productivity and efficiency of the industry. These efforts have, however, some degree of controversy. The purpose of this paper is, therefore, threefold. First it summarises the key structural findings that have been determined from past research into the construction industry in New Zealand. Secondly it makes some comparisons between the construction industry's productivity in New Zealand with that of the six states of Australia. Finally it also considers potential areas for potential future research.
\end{abstract}

\section{Introduction}

Over the years attempts have been made to determine the reasons behind the differences in productivity and income between New Zealand and Australia. One area where this gap in productivity is regarded as being most marked is in the case of the construction industry. In the case of New Zealand this perceived gap has been recognised by official statistics, which seems to show that the construction industry has a productivity level at much the same level that it was in the late 1970s (Statistics New Zealand 2012, Industry productivity statistics). A number of possible reasons have been put forward for this gap between the Australian and New Zealand construction industries, including such things in the latter country as low economies of scale in the industry, a lack of competition, regulatory impediments, faulty innovation and management practice, poor investment quality and a low levels of skills (New Zealand, Department of Building and Housing, Productivity Taskforce 2009; Van Dai Tran 2010; New Zealand Productivity Commission 2011). One aspect that has received less attention has been the validity of the productivity measures themselves, which in a number of cases overseas such as in the United States have been the subject of some controversy.

The aim of this paper is to discuss some of the issues surrounding the estimation of productivity levels in the construction industry, to review past productivity analysis that has been conducted on the New Zealand construction industry and then to undertake productivity estimates of the New Zealand industry using a data envelopment approach (DEA), which involves a comparison of New Zealand figures with those of the various state based jurisdictions of Australia.

The paper is structured as follows. In the first section the general background to the issue of productivity in New Zealand and Australia is given. A section is then provided that examines past studies of productivity in the construction industry in New Zealand (and references the major Australian work). The method used in this paper is then provided. A section which gives estimates of the productivity level of the industry in Australia and New Zealand follows, and in the final section some conclusions are made.

\section{Background}

New Zealand and Australia are similar countries in that they are both geographically isolated from the world's major markets, are sparsely populated, have populations of 
predominately British background, as well as similar common-law based legal systems. The structure of the two economies is also similar in that they both specialise in the export of mainly resource based commodities to the countries of the Asia-Pacific region. Despite these similarities, Australia has a considerably higher per capita GDP than New Zealand of US $\$ 40,800$, (2011) compared to only US $\$ 28,000$ (Central Intelligence Agency 2012. The large per capita output gap between Australia and New Zealand is a relatively new phenomenon. Up until the 1970s average output and income of the two countries were of similar size, but during that decade a substantial gap between the two countries opened up. Both countries went through a process of economic reform in the 1980s and 1990s and despite these reforms being similar in character (although undertaken at a faster rate in New Zealand); the gap in living standards that had opened up in the 1970s has persisted.

Given the similarity of the two countries it would be expected that over the longer term some sort of convergence would have occurred between the two countries. The economic theory of 'convergence' suggests that over time, wealthy countries will end up at around the same level of income, as technology and ideas spill over between them. In the case of Australia and New Zealand it would normally be expected that given the similarities of the two countries these spillovers from the former to the latter would be considerable, and would bring about an eventual convergence. This expected convergence, did not occur during the 1990s and 2000s (Conway and Hunt 1998).

In recent years a number of researchers and policy groups have attempted to put forward reasons for the persistence in the gap in average output and income levels between the two countries. These reasons include the following.

1. Smaller population in New Zealand than Australia. New Zealand's market of 4.2 million people does not allow for as much depth, development and economies of scale as does Australia's population of around 20.9 million. New Zealand's small population means that firms in that country will reach their limit in terms of domestic growth fairly quickly, and will then have to export or merge with a larger company to expand further. Smaller markets might also mean less competition with the result being less pressure on companies to operate at high levels of efficiency. The isolation of New Zealand from world markets intensifies this problem and reduces the gains from economies of scale and externalities between businesses, which occurs in large, globalised cities (McCann 2009).

2. A greater abundance of natural resources in Australia. Another common explanation for Australia's higher income has been luck, in the form of its abundant mineral resources. In recent times, however, New Zealand has also experienced a boom in commodity prices, with rising demand for agricultural products.

3. Low household savings. Some have argued that the New Zealand's low level of saving is a weakness. This forces firms to borrow money from overseas lenders, who charge higher interest rates, and thereby encourage less investment (Skilling 2004). Some doubts have been expressed about the importance of this explanation in recent times New Zealand's long-term real interest rates and real cost of capital are, as it happens, similar to Australia's (Cameron et. al. 2007; Lally 2000).

4. Policy. Improving the policy environment has been a goal of economic reform in New Zealand since 1984, with deregulation, privatisation, trade liberalisation, and tax cuts. In the case of Australia, however, similar reforms have occurred and the level of regulation across the two countries is of a similar level. Both countries tend to rank fairy highly in international rankings of freedom and competitiveness. ${ }^{1}$

\footnotetext{
${ }^{1}$ World Bank (2011); The Heritage Foundation (2012); World Economic Forum (2011).
} 
5. Lower levels of labour productivity. Lower levels of labour productivity in New Zealand, which in turn are driven by lower levels of investment in physical capital and human capital. This last reason seems the most likely to be true but begs the question of why there may be less investment in physical and human capital in New Zealand than Australia. It could be that there is a lack of investment opportunities and that returns are too low. For New Zealand firms and investors, the returns are either too low compared to investments that could be made overseas, or not worth the risk. Another explanation could be the lower relative cost of labour. Australia has a more rigid, unionised system of industrial relations than New Zealand, with a high minimum wage and national awards that set pay levels. This makes it expensive to hire staff, and therefore more rewarding to invest in capital.

Whatever the reasons there might be, there is considerable evidence that labour productivity and productivity levels in general in New Zealand in many sectors are simply lower than they are in Australia, which in turn explains the lower levels of income in New Zealand. No sector is perceived to illustrate this problem more than that of the construction industry, where there appears to be a considerable gap between productivity levels in Australia compared to New Zealand. In terms of the construction industry it is possible to gain some appreciation of some of these issues by simply comparing education, profit levels and average business size across the two countries (Tables 1 to 3 ).

\begin{tabular}{|l|c|c|c|c|c|c|c|c|}
\hline & $\begin{array}{c}\text { Post- } \\
\text { graduate } \\
\text { Degree }\end{array}$ & $\begin{array}{c}\text { Graduate } \\
\text { Diploma \& } \\
\text { Graduate } \\
\text { Certificate }\end{array}$ & $\begin{array}{c}\text { Bachelor } \\
\text { Degree }\end{array}$ & $\begin{array}{c}\text { Advanced } \\
\text { Diploma } \\
\&\end{array}$ & Certificate & $\begin{array}{c}\text { Inadequately } \\
\text { descriped/ } \\
\text { Not stated }\end{array}$ & $\begin{array}{c}\text { Total } \\
\text { qualifications }\end{array}$ & $\begin{array}{c}\text { Total } \\
\text { employed }\end{array}$ \\
\hline Australia & 4,619 & 2,441 & 35,237 & 34,796 & 321,946 & 33,557 & 432,596 & 709,840 \\
\hline$\%$ & 0.7 & 0.3 & 5.0 & 4.9 & 45.4 & 4.7 & 60.9 & \\
\hline $\begin{array}{l}\text { New } \\
\text { Zealand }\end{array}$ & 717 & 681 & 5,394 & 10,908 & 87,363 & 5,733 & 110,796 & 149,370 \\
\hline$\%$ & 0.5 & 0.5 & 3.6 & 7.3 & 58.5 & 3.8 & 74.2 & \\
\hline
\end{tabular}

Table 1 Education levels of the construction workforce in Australia and New Zealand, Construction 2006

Source: Australian Bureau of Statistics, Census of population and housing, cat. no. 2001.0. Statistics New Zealand, 2006 Census

\begin{tabular}{|c|c|c|c|c|c|c|c|c|}
\hline & \multicolumn{4}{|c}{ New Zealand } & \multicolumn{4}{c|}{ Australia } \\
\cline { 2 - 11 } & $\begin{array}{c}\text { Income } \\
\text { \$m NZ }\end{array}$ & $\begin{array}{c}\text { Expenditure } \\
\$ \mathrm{~m} \mathrm{NZ}\end{array}$ & $\begin{array}{c}\text { EBIT } \\
\$ \mathrm{~m} \mathrm{NZ}\end{array}$ & $\begin{array}{c}\text { Profit } \\
\text { margin \% }\end{array}$ & $\begin{array}{c}\text { Income } \\
\$ \mathrm{~m} \mathrm{Au}\end{array}$ & $\begin{array}{c}\text { Expenses } \\
\$ \mathrm{~m} \mathrm{Au}\end{array}$ & $\begin{array}{c}\text { EBIT } \\
\$ \mathrm{~m} \mathrm{Au}\end{array}$ & $\begin{array}{c}\text { Profit } \\
\text { margin \% }\end{array}$ \\
\hline 2002 & 16,570 & 15,232 & 1,952 & 11.8 & 123,328 & 112,596 & 11,232 & 9.1 \\
\hline 2003 & 18,730 & 17,271 & 2,096 & 11.2 & 140,984 & 128,960 & 13,078 & 9.3 \\
\hline 2004 & 20,872 & 19,383 & 2,333 & 11.2 & 159,928 & 145,434 & 15,935 & 10.0 \\
\hline 2005 & 23,391 & 25,902 & 3,394 & 14.5 & 174,162 & 157,655 & 16,930 & 9.7 \\
\hline 2006 & 32,734 & 29,517 & 4,275 & 13.1 & 198,802 & 179,329 & 19,485 & 9.8 \\
\hline 2007 & 34,507 & 30,640 & 5,043 & 14.6 & 233,348 & 202,348 & 33,896 & 14.5 \\
\hline 2008 & 38,104 & 34,749 & 3,893 & 10.2 & 253,820 & 234,279 & 28,227 & 11.1 \\
\hline 2009 & 36,965 & 34,991 & 2,231 & 6.0 & 260,154 & 240,499 & 29,010 & 11.2 \\
\hline 2010 & 33,451 & 31,263 & 1,972 & 5.9 & 275,290 & 254,002 & 31,308 & 11.4 \\
\hline
\end{tabular}

Table 2 Returns to business in the New Zealand and Australian construction industry

Source: Statistics New Zealand, Annual enterprise survey. Australian Bureau of Statistics, Australian industry, cat. no. 8155.0. EBIT- Earnings before interest and tax. Profit margin-EBIT/Income

Abbott, M and Carson, C (2013) 'A comparative approach to determining the growth of productivity of the New Zealand construction industry', Australasian Journal of Construction Economics and Building, 13 (4) 65-77 
In the case of education there does not appear to be any lower level of education overall in the New Zealand industry (Table 1) compared to Australia, except to say the mix of qualifications is somewhat different (i.e. degrees versus diplomas). In the New Zealand case the latter type of qualification seems more popular. Likewise levels of profitability in the industry seem to be of comparable level (Table 2), so it would be expected that investment levels would be similar. Finally the average size of businesses in the construction industry in New Zealand is smaller than that of Australia (Table 3), probably a product of the greater dominance of the Australian economy by large sized state capital cities such as Melbourne, Sydney and Brisbane. In light of these factors it is difficult to determine why there should be estimated in the case of the New Zealand industry a significant stagnation of productivity compared to the Australian case.

\begin{tabular}{|c|c|c|c|c|c|c|}
\hline & \multicolumn{3}{|c|}{ Australia } & \multicolumn{3}{c|}{ New Zealand } \\
\cline { 2 - 7 } & $\begin{array}{c}\text { Enterprises } \\
\text { no. }\end{array}$ & $\begin{array}{c}\text { Employed } \\
\text { no. }\end{array}$ & $\begin{array}{c}\text { Employed/ } \\
\text { enterprises }\end{array}$ & $\begin{array}{c}\text { Enterprises } \\
\text { no. }\end{array}$ & $\begin{array}{c}\text { Employed } \\
\text { no. }\end{array}$ & $\begin{array}{c}\text { Employed/ } \\
\text { enterprises }\end{array}$ \\
\hline 2000 & 309,691 & 688,000 & 2.2 & 41,389 & 75,970 & 1.8 \\
\hline 2001 & 341,457 & 670,500 & 2.0 & 40,181 & 76,560 & 1.9 \\
\hline 2002 & 344,561 & 693,300 & 2.0 & 39,485 & 80,370 & 2.0 \\
\hline 2003 & 339,982 & 717,800 & 2.1 & 41,168 & 87,410 & 2.1 \\
\hline 2004 & 365,780 & 773,700 & 2.1 & 44,715 & 97,630 & 2.2 \\
\hline 2005 & 383,515 & 832,800 & 2.2 & 47,971 & 110,870 & 2.3 \\
\hline 2006 & na & 877,400 & $n a$ & 50,813 & 119,200 & 2.3 \\
\hline 2007 & 351,612 & 973,000 & 2.8 & 52,263 & 125,710 & 2.4 \\
\hline 2008 & 349,118 & 983,000 & 2.8 & 54,139 & 131,140 & 2.4 \\
\hline 2009 & 342,436 & 983,000 & 2.9 & 53,191 & 122,110 & 2.3 \\
\hline
\end{tabular}

Table 3 Average size of construction enterprises in New Zealand and Australia

Source: Statistics New Zealand, Business demography statistics. Australian Bureau of Statistics, Australian industry, cat. no. 8155.0

\section{Past Measures of Productivity}

Over the years a number of researchers in New Zealand have made estimates of New Zealand's productivity change (for a more detailed overview of studies of this sort see Abbott and Carson 2012). In some of these cases researchers broke down their estimates into industry sectors, including that of the construction industry. Industry breakdowns that include the construction industry occurred in the following studies: Orr (1989); Chapple (1994); Philpott (1991, 1993, 1995); Fare, Grosskopf and Margaritis (1996), Diewert and Lawrence (1999); Black, Guy \& McLellan; Mason \& Osborne (2007) and Janssen \& McLoughlin (2008). In addition Davis (2007) undertook a study that concentrated just on construction productivity.

Figures 1 and 2 provide a summary of some of these works on the productivity of the construction industry. As can be seen from Figure 1 the estimates of productivity in the construction industry tended to rise through the 1960s and early 1970 s, before peaking around 1976 and then declining. A recovery in productivity appears to have taken place in the early 1980s. Figure 2 provides more pessimistic estimates. In each case the estimates of productivity appear to show a stagnation of growth in productivity. In the Australian case some studies have also shown that there has been a slowdown of productivity growth (see for instance: Parham and Zheng 2006; Li and Liu 2010; KPMG Econtech 2010).

Regardless of the periods selected it appears from the various studies that although construction productivity increased to some degree up until the mid-1970s, since then the results have been mixed. This appears to be the case even though there have certainly

Abbott, M and Carson, C (2013) 'A comparative approach to determining the growth of productivity of the New Zealand construction industry', Australasian Journal of Construction Economics and Building, 13 (4) 65-77 
been a range of technological changes that have occurred in the industry since then. New tools and equipment have been introduced that have tended to be labour savings. This has mean the introduction of hand held powered tools (nail drivers, sanders, saws and drills), and improved lifting and moving machinery (cranes, loaders, earth movers, graders, forklifts). New materials and processes have also been introduced along with a greater use of pre-fabricated materials.

The introduction and greater use of new equipment, materials and processes has meant that it is hard to explain why growth in the productivity of the New Zealand construction industry has been sluggish. One possible explanation is that the various studies of productivity growth may have underestimated the growth in output of the industry, and therefore productivity. This explanation has been forward for a variety of reasons in the case of the United States, where a similar slowdown in productivity growth was estimated in the 1970s and 1980s. In the American context some thought that this decline could be explained by the use of inappropriate price indexes (Dacy 1965; Stokes 1981). Rosefielde and Mills (1979), in contrast, argued that official data did not fully account for changes in quality and so tried to adjust for changes in the scale and structure of the quality of output. They argued that as construction is locationally immobile and designed to achieve some particular function, at some specific site, a diverse and changing type off output is produced by the industry. This coupled with a changing composition of materials makes it difficult to measure quality improvements over time, which in turn leads to an underestimation of output levels, and therefore productivity improvements. Schriver and Bowlby (1985) also found that much of the fall in productivity could be attributed to a change in the output mix from high to low productivity building projects.

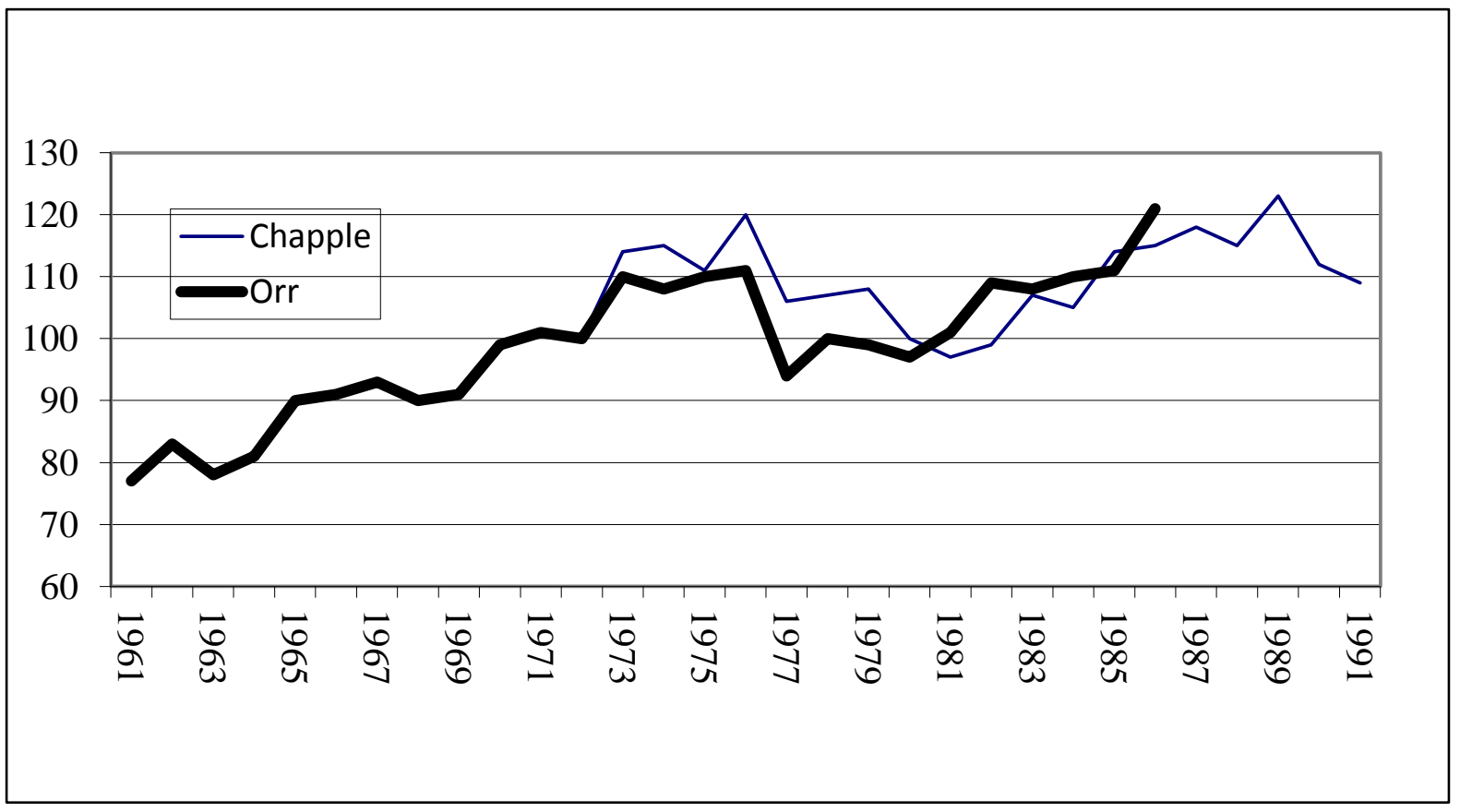

Figure 1 Total factor productivity in New Zealand construction, 1972=100

Source: Orr 1989; Chapple 1994

In using quality adjusted figures for output Rosefielde and Mills relied upon the work of Cassimatis who used the number of rooms per dwelling and square footage of buildings as an indicator of the quality of output. In the New Zealand case past studies have all used some constant dollar valuation of the industry's production as an indication of output, which assumes that this value reflects any changes that are occurring in quality and size, whether it be in terms of area or other form of quality. This might, perhaps, be a fair assumption but

Abbott, M and Carson, C (2013) 'A comparative approach to determining the growth of productivity of the New Zealand construction industry', Australasian Journal of Construction Economics and Building, 13 (4) 65-77 
nowhere has it been justified, and if it is not a fair assumption may have led to some distortion of results.

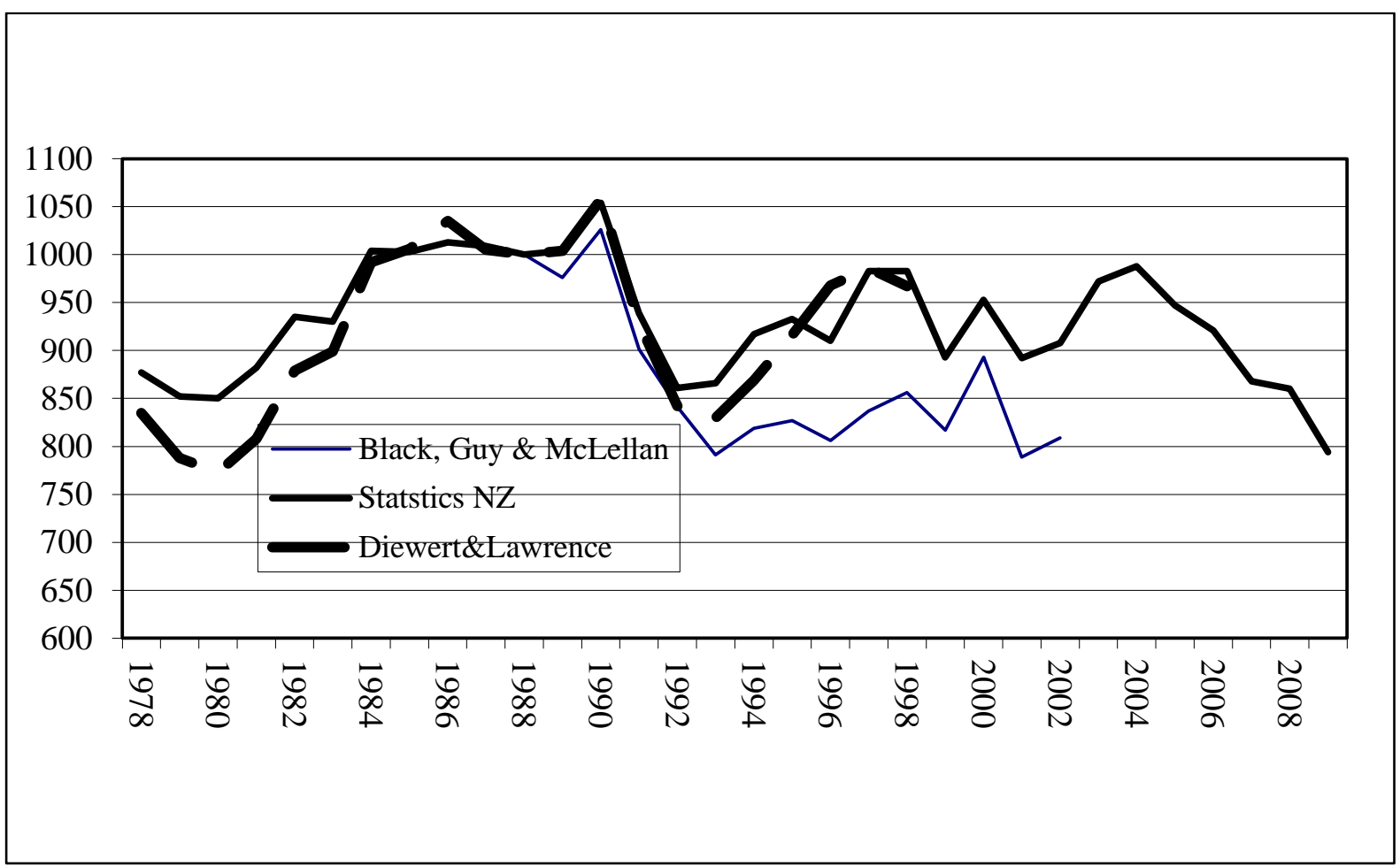

Figure 2 Total factor productivity of the New Zealand, 1978=1000 construction industry

Source: Statistics New Zealand 2012, Industry productivity statistics. Diewert \& Lawrence 1999, Black, Guy \& McLellan 2003

One way of accounting for this issue in the New Zealand context would be simply to make use of the square metres of area constructed as an indicator of output, rather than some monetary valuation of property. In addition to avoiding the issue of quality it would also avoid the issue of defective price indexes mentioned earlier. In the New Zealand case Statistics New Zealand has data on building consents for area to be constructed for residential housing from 1974 onwards and for non-residential construction from 1991. As construction also involves work on altering existing building as well as the construction of major engineering projects some indicator of output for this sector would also need to be used. In order to achieve this, a productivity analysis method would need to be used, which enables the combination of different measures of output (i.e. floor area and value added). Luckily the DEA approach is ideal for this purpose.

\section{Methodology}

In order to incorporate the physical indicators of output, such as square metres, with financial indicators, such as the dollar of value added, the DEA method can be used. DEA was pioneered by Charnes et al (1978) and based on the earlier work by Farrell (1957). There are many texts offering a detailed discussion on DEA, including the algorithms used (see, for example, Lovell and Schmidt 1988; Fare, Grosskopf and Lovell 1985; and Coelli, et. al. 2005). DEA is a linear programming technique which estimates organisational efficiency by measuring the ratio of total inputs employed to total output produced for each organisation (or country or industry sector). This ratio is then compared to others in the sample group to derive an estimate of relative efficiency.

DEA identifies the most efficient providers of a good or service by their ability to produce a given level of output using the least number of inputs. Other organisations in the sample 
group receive an efficiency score determined by the variance in their ratio of inputs employed to outputs produced relative to the most efficient producer in the sample group. DEA is therefore a measure of relative efficiency against the sample group's benchmark best practice. If input and output prices are used then allocative, and technical efficiency levels can be determined. If prices are not available, or distorted, then DEA can be used to estimate levels of technical efficiency. Technical efficiency under constant returns to scale can be decomposed into scale efficiency and pure technical efficiency under variable returns to scale. Scale efficiency can be defined as being the extent to which an organisation can take advantage of returns to scale by altering its size towards the optimal scale. Pure technical efficiency on the other hand is determined by the difference between the observed ratio of combined quantities of output to input and the ratio achieved by best practice. In studies taken over time total factor productivity change can be estimated using the DEA approach, which is comprised of technical efficiency change and technological change. Technical efficiency change is a movement towards the best practice frontier. Technological change is the movement of the frontier.

The advantage of this approach is that it can be used without input or output prices to determine levels of technical efficiency (pure and scale), which when used in the case of the construction industry might lead to distorted results. DEA has been used to extensively in a number of industries to assess productivity and efficiency levels (especially public sector providers and utilities where prices either don't exist or are distorted by abuses of market power). In the case of the construction industry only a small number of studies have been undertaken using this approach. This is regrettable as studies of the productivity of the construction industry often run into difficulties in finding adequate price indices. Examples of the DEA approach in the construction industry include studies by Chau and Wang (2005), Wang (1998); Wang and Chau $(1997,2001)$ on the Hong Kong industry and in the case of New Zealand a single study by Fare, Grosskopf and Margaritis (1996).

It is possible, using the DEA approach, to combine two indicators of output (square metres residential constructed, and the value of new alterations undertaken plus engineering and commercial construction) with two indicators of input (labour employed and net capital stock used) over the period 1991 to 2010. Furthermore it is possible to combine the estimates of the New Zealand results with those of the state based jurisdictions in Australia. Data for the years 1991 to 2010 can be obtained from the Australian Bureau of Statistics and Statistics New Zealand. ${ }^{2}$ Monetary figures (i.e. for non-residential construction and net capital stock) are converted into constant \$US, using the purchasing parity in order to make the Australian and New Zealand figures comparable.

\section{New Zealand and Australian Construction Productivity Figures}

To begin with it is possible to see if the use of a physical indicator of output (i.e. floor area) has any impact on the productivity results. Tables 4 and 5 benchmark the Australian state based construction industries with that of New Zealand using data from between the years 1991 and 2010. The difference between the two tables is that in the first, the value added of the construction industry is used as the output, whereas in the second table to determine the level of new residential building activity the figures for square metres of floor area is used rather than value added (with alterations commercial and engineering construction continuing to use value added). In both cases the inputs used are the numbers employed in industry and the value of the net capital stock.

\footnotetext{
${ }^{2}$ Australian Bureau of Statistics: Residential floor area - Building approvals, Australia, cat no. 8731.0; Value added - Australian national accounts, cat. no. 5220.0; Labour - Labour force, Australia, cat. no. 6291.0; Capital stock - Australian national accounts, cat. no. 5220.0.

Statistics New Zealand: Residential floor area - Building consents issued; Value added: National accounts; Labour - Household labour force survey; Capital stock - National accounts.
}

Abbott, M and Carson, C (2013) 'A comparative approach to determining the growth of productivity of the New Zealand construction industry', Australasian Journal of Construction Economics and Building, 13 (4) 65-77 
In Table 4 there does appear to be a considerable gap in the level of efficiency of the New Zealand industry compared to that of the Australian state based industries. The level of technical efficiency is only 0.505 compared to a mean of 0.816 for all seven jurisdictions. In the second case, however, this gap has largely disappeared. In Table 5 the New Zealand level of technical efficiency is 0.846 compared to a mean of 0.897 for all seven jurisdictions. What is notable is that the New Zealand level is really only lower than the two main states of Western Australia and Queensland, states that have a disproportionately high level of engineering construction, rather than residential construction.

What this means is that the residential construction industry in New Zealand is not especially inefficient compared to that of the Australian industry in building square metres of floor area. This is reflected in the higher level of efficiency when this measure is used. Instead as the New Zealand residential industry tends to use lower value materials (timber versus brick), the low productivity measures in Table 4 are probably largely caused by prices indices creating a lower level of value added as an indication of output. What does help to create a gap between the two countries in productivity is probably caused by the larger proportion of large scale engineering projects in states like Western Australia and Queensland, as well as differences in productivity levels in this sector of the construction industry. What this means is that the composition of the industry in different jurisdictions has important implications for the evaluation of relative productivity.

\begin{tabular}{|l|c|c|c|}
\hline & Technical efficiency & Pure technical efficiency & Scale efficiency \\
\hline New South Wales & 0.778 & 1.000 & 0.778 \\
\hline Victoria & 0.803 & 0.915 & 0.878 \\
\hline Queensland & 0.940 & 1.000 & 0.940 \\
\hline South Australia & 0.687 & 0.699 & 0.984 \\
\hline Western Australia & 1.000 & 1.000 & 1.000 \\
\hline Tasmania & 1.000 & 1.000 & 1.000 \\
\hline New Zealand & 0.505 & 0.533 & 0.948 \\
\hline $\begin{array}{l}\text { Mean (for all states } \\
\text { \& New Zealand) }\end{array}$ & 0.816 & 0.878 & 0.932 \\
\hline
\end{tabular}

Table 4 Efficiency levels 1991-2010 Australian and New Zealand jurisdictions (output=value added; inputs=labour \& capital stock)

\begin{tabular}{|l|c|c|c|}
\hline & Technical efficiency & Pure technical efficiency & Scale Efficiency \\
\hline New South Wales & 0.704 & 1.000 & 0.704 \\
\hline Victoria & 0.917 & 1.000 & 0.917 \\
\hline Queensland & 1.000 & 1.000 & 1.000 \\
\hline South Australia & 0.810 & 0.838 & 0.966 \\
\hline Western Australia & 1.000 & 1.000 & 1.000 \\
\hline Tasmania & 1.000 & 1.000 & 1.000 \\
\hline New Zealand & 0.846 & 0.852 & 0.993 \\
\hline $\begin{array}{l}\text { Mean (for all states } \\
\text { \& New Zealand) }\end{array}$ & 0.897 & 0956 & 0.940 \\
\hline
\end{tabular}

Table 5 Efficiency levels 1991-2010 Australian and New Zealand jurisdictions (output=residential floor area \& value added; inputs=labour \& capital stock)

Abbott, M and Carson, C (2013) 'A comparative approach to determining the growth of productivity of the New Zealand construction industry', Australasian Journal of Construction Economics and Building, 13 (4) 65-77 
If the floor area/value added as output approach is used in determining productivity change over time more optimistic results are obtained. Table 6 provides data on the total factor productivity change over the period 1990 to 2010 . What is found in these estimations is that the Australian industry is relatively stagnant in terms of productivity improvements over the period. The average productivity change over the period is -1.1 per annum for the seven jurisdictions together (as indicated by the figure 0.989).

\begin{tabular}{|l|c|c|c|c|c|}
\hline & $\begin{array}{c}\text { Technological } \\
\text { change }\end{array}$ & $\begin{array}{c}\text { Technical } \\
\text { Efficiency } \\
\text { change }\end{array}$ & $\begin{array}{c}\text { Pure } \\
\text { efficiency } \\
\text { change }\end{array}$ & $\begin{array}{c}\text { Scale } \\
\text { efficiency } \\
\text { change }\end{array}$ & $\begin{array}{c}\text { Total Factor } \\
\text { Productivity } \\
\text { change }\end{array}$ \\
\hline New South Wales & 0.940 & 1.000 & 1.000 & 1.000 & 0.940 \\
\hline Victoria & 0.983 & 0.999 & 1.000 & 0.999 & 0.983 \\
\hline Queensland & 0.985 & 0.992 & 0.992 & 0.999 & 0.977 \\
\hline South Australia & 0.996 & 0.995 & 1.000 & 0.005 & 0.991 \\
\hline Western Australia & 0.996 & 1.000 & 1.000 & 1.000 & 0.996 \\
\hline Tasmania & 1.007 & 1.004 & 1.005 & 0.999 & 1.010 \\
\hline New Zealand & 1.034 & 0.992 & 0.994 & 0.998 & 1.026 \\
\hline $\begin{array}{l}\text { Mean (for all states \& } \\
\text { New Zealand) }\end{array}$ & 0.991 & 0.997 & 0.999 & 0.999 & 0.989 \\
\hline
\end{tabular}

Table 6 Total Factor Productivity change, Australia and New Zealand, 1990 to 2010

In the New Zealand case, however, there does appear to be some improvement over the period (growth of productivity of 2.6 per cent per annum). This growth in productivity in New Zealand seems to indicate that there is some convergence throughout the period. Figure 3 provides estimates of the annual growth in productivity of the New Zealand construction industry and estimates for the whole economy produced by Statistics New Zealand. Although the growth of productivity of the New Zealand construction industry appears to be cyclical (strong in periods of economic growth such as the early to id 1990s and mid-2000s, it does seem to fluctuate to a greater degree than that of the economy as a whole.

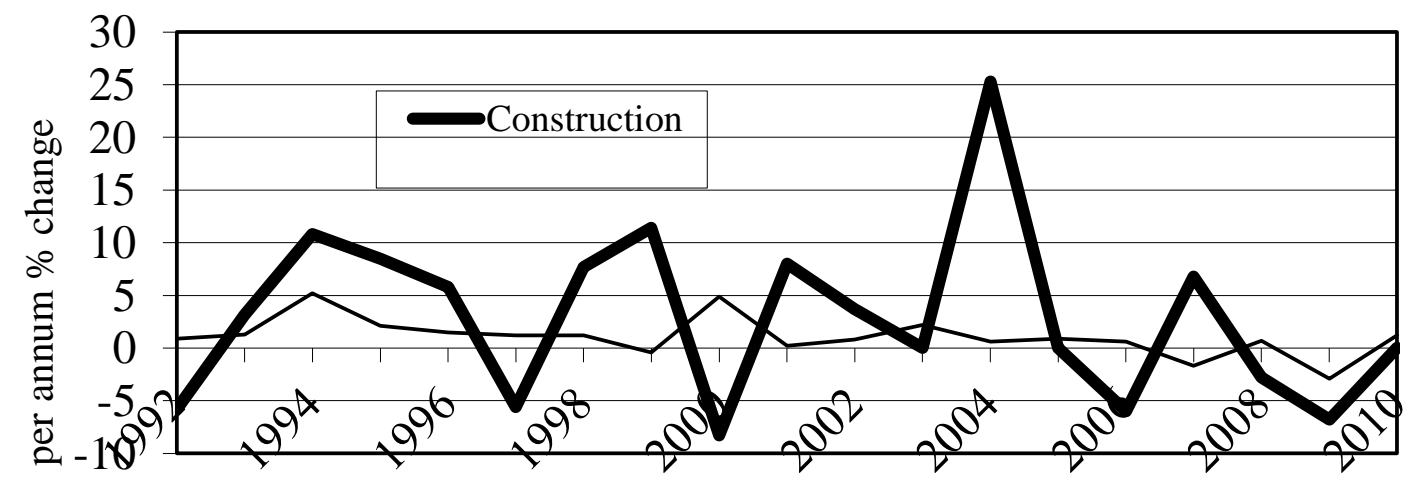

Figure 3 Productivity growth, construction and whole economy, New Zealand 1991 to 2010 Source: Statistics New Zealand 2012, Industry productivity statistics

Abbott, M and Carson, C (2013) 'A comparative approach to determining the growth of productivity of the New Zealand construction industry', Australasian Journal of Construction Economics and Building, 13 (4) 65-77 
Growth of productivity in New Zealand's construction industry, therefore, appears from these figures to be stronger than growth overall in the economy, but perhaps this is because the industry is coming off a low base after stagnant periods of productivity growth from the mid1970s, until the late 1980s. These results are in line with those studies that show an uptake in productivity from the early-1990s, and work that shows similar levels of productivity in the Auckland building industry to those in major centres in Australia. In the latter case Best (2008), for instance, found that in the construction of standard sized hotel complexes the productivity of the industry in Brisbane, Melbourne, Sydney and Auckland was of comparable levels.

\section{Conclusion}

In light of the work presented in this paper a number of conclusions can be made. The first is that in the case of the estimation of the productivity change in the New Zealand construction industry the manner in which the outputs are defined can have a crucial impact on the results; just as was the case in earlier American studies. The use of prices indices in determined output levels and changes in quality and location can affect the nature of the outputs and therefore productivity levels.

Bearing this in mind some hesitant conclusions can be made. First of all productivity in the New Zealand construction probably has grown through the period 1991 to 2010 . Even if it can be shown that the industry's productivity growth was reduced in the period 1975 to 1990 there is reason to believe that the performance has been better in more recent years.

The second conclusion that can be made is that the New Zealand industry does have productivity levels similar to those in some Australian jurisdictions although there does appear to be a gap between that of New Zealand and some jurisdictions (i.e. Queensland and Western Australian). In all likelihood this is due to the composition of the construction industry as those Australians states with the highest level of productivity tend to be those states with the highest proportion of construction in heavy engineering projects rather than residential and commercial construction. Attempts by policy makers to encourage improvements of construction industry productivity should be mindful of the differences in the composition of the industry across different jurisdictions.

This conclusion does not mean that the New Zealand industry by any means is close to world's best practice levels of productivity, but instead are just on a similar level to its near neighbour.

Finally it is clear that the notion of the level of productivity is a complex one in the case of the construction industry. A need for further experimentation with methods of approach needs to be undertaken before any really firm conclusions can be made.

\section{References}

Abbott, M. \& Carson, C. 2012, 'A review of productivity analysis of the New Zealand construction industry', Australasian Journal of Construction and Building Economics, 12 (3), 1-15

Australian Bureau of Statistics, 2012, Australian Industry, cat no. 8155.0, ABS, Canberra

Australian Bureau of Statistics, 2012, Australian National Accounts, cat. no. 5220.0, ABS, Canberra

Australian Bureau of Statistics, 2012, Building Approvals, Australia, cat. No. 8731, ABS, Canberra

Australian Bureau of Statistics, 2006, Census of Population and Housing 2006, cat. no. 2001.0, ABS, Canberra

Abbott, M and Carson, C (2013) 'A comparative approach to determining the growth of productivity of the New Zealand construction industry', Australasian Journal of Construction Economics and Building, 13 (4) 65-77 
Australian Bureau of Statistics, 2012, Labour Force: Australia, cat. no. 6291.0, ABS, Canberra

Best, R. 2008, 'The Development and Testing of Purchasing Power Parity Method for Comparing Construction Costs Internationally', PhD Thesis, University of Technology Sydney, Sydney

Black, M., Guy, M. \& McLellan, N. 2003, Productivity in New Zealand 1988 to 2002, Treasury Working paper 03/06, The Treasury, Wellington

Cameron, L., Chapple, B., Davis, N., Kousis, A., \& Lewis, G. 2007, New Zealand Financial Markets, Saving, and Investment, Policy Perspectives Paper 07/01, New Zealand Treasury, Wellington

Central Intelligence Agency, 2012, CIA Factbook, CIA, Washington

Chapple, S. 1994, 'Searching for the Heffalump?', Anexploration into sectoral productivity and growth in New Zealand', New Zealand Institute of Economic Research Working paper 99/10, Wellington

Charnes, A. Cooper, W.W \& Rhodes, E. 1978, 'Measuring the efficiency of decision making units, European journal of operational research, 2 (6), 429-444

Chau, K.W. \& Wang, Y.S. 2005, 'An analysis of productivity growth in the construction industry: a non-parametric approach', in Khosrowshahi, F. ed. $21^{\text {st }}$ Annual ARCOM conference, 7-9 September 2005, SOAS, University of London, Association of Researchers in Construction Management, vol. 1, 159-69

Coelli, T., Prasada Rao, D.S. \& Battese, G.E. 1998, An introduction to efficiency and productivity Analysis, Boston, Kluwer

Conway, P. \& Hunt, B. 1998, 'Productivity growth in New Zealand: economic reform and the convergence hypothesis', Reserve Bank of New Zealand, Internal Paper, Economics Department, February, Wellington

Dacy, D.C. 1965, 'Productivity and price trends in construction since 1947', Review of Economics and Statistics, 47 (4), 406-411

Davis, N. 2007, Construction Sector Productivity Scoping Report, MartinJenkins, Wellington

Diewert, E. \& Lawrence, D. 1999, Measuring New Zealand's Productivity, Treasury Working Paper 99/5, Treasury, Wellington

Fare, R., Grosskopf, S. \& Knox Lovell, C.A. 1985, The Measurement of Efficiency of Production, Kluwer-Nijhoff, Boston.

Fare, R. Grosskopf, S. \& Margaritis, D. 1996, 'Productivity growth' in A study of Economic Reform: the Case of New Zealand, B. Silverstone, A. Bollard, \& R. Lattimore, eds., Elsevier Science, New York

Farrell, M. 1957, 'The measurement of productive efficiency', Journal of the Royal Statistical Society, Series A, CXX, 253-81

Janssen, J. \& McLoughlin, S. 2008, New Zealand's Productivity Performance, New Zealand Treasury Productivity Paper 08/02, The Treasury, Wellington

KPMG Econtech, 2010, Economic Analysis of Building and Construction Industry Productivity, Report prepared for the Master Builders Australia, Melbourne

Lally, M. 2000, The Real Cost of Capital in New Zealand: is it too High?, New Zealand Business Roundtable, Wellington

$\mathrm{Li}$, Y. \& Liu, C. 2010, 'Malmquist indicies of total factor productivity in the Australian construction industry', Construction Management and Economics, 28, 933-45 
Lovell, C.A. Knox \& Schmidt, P. 1988, 'A comparison of alternative approaches to the measurement of productive efficiency', in Applications of Modern Production Theory: Efficiency and Productivity. eds. A. Dogramaci \& R. Färe, Kluwer, Boston

McCann, P. 2009, 'Economic geography, globalization and New Zealand's productivity paradox', New Zealand Economic Papers, 43 (3), 279-314

Mason, G. \& Osborne, M. 2007, Productivity, Capital-Intensity and Labour Quality at Sector Level in New Zealand and the UK, New Zealand Treasury Working Paper 07/01, Wellington.

New Zealand, Department of Building and Housing, Productivity Taskforce, 2009, Report of the Building and Construction Sector Productivity Taskforce: a Modern Efficient and Productive New Zealand Built Infrastructure Industry, N.Z.: Dept. of Building and Housing, Wellington

New Zealand, Productivity Commission, 2011, Housing Affordability Inquiry: Draft Report, Productivity Commission, Wellington

New Zealand Institute of Economic Research, 2006, New Zealand-Australian Income Differential, NZIER, Wellington

Organisation of Economic Cooperation and Development, 2011, GDP PPPs and Derived Indices for OECD Countries, OECD, Paris

Parham, D., \& Zheng, S., 2006, 'Aggregate and industry productivity estimates for Australia', Australian Economic Review, 39 (2), 216-26

Philpott, B. 1991, 'Economic growth in New Zealand models and Experience', in Long Run Perspectives on the New Zealand economy. Proceedings of the Sesqicentennial Conference of the New Zealand Association of Economists, New Zealand Association of Economists, Wellington

Philpott, B. 1993, 'Data for sectoral productivity analysis and some preliminary results for 1978-93', RPEP Paper 256

Philpott, B. 1995, New Zealand's Aggregate and Sectoral Productivity Growth 1960-1995, Research Project on Economic Planning Paper 274, Victoria University of Wellington, October, Wellington

Rosenfielde, S. \& MillsD.Q. 1979, 'Is construction technologically stagnant?', in J.E. Lange \& D.Q. Mills, eds., The Construction Industry, D.C. Heath and Company, Lexington MA

Schriver, W.R. \& Bowlby, R.L. 1985, 'Changes in productivity and composition of output in building construction, 1972-1982', Review of Economics and Statistics, 67 (2), 318-322

Skilling, D. 2004, Investment, Savings, and Growth, New Zealand Institute, Auckland

Statistics New Zealand, 2006, 2006 Census of Population and Dwellings, Statistics New Zealand, Wellington

Statistics New Zealand, 2012, Annual Enterprise Survey, Statistics New Zealand, Wellington Statistics New Zealand, 2012, Building Consents Issued, Statistics New Zealand, Wellington Statistics New Zealand, 2012, Business Demography Statistics, Statistics New Zealand, Wellington

Statistics New Zealand 2012, Household Labour Force Survey, Statistics New Zealand, Wellington

Statistics New Zealand 2012, Industry Productivity Statistics, 1978-2009, Statistics New Zealand, Wellington

Statistics New Zealand 2012, National Accounts, Statistics New Zealand, Wellington

Stokes, H.K. 1981, 'An examination of the productivity decline in the construction industry', Review of Economics and Statistics, 63 (4), 495-502 
The Heritage Foundation, 2012, 'Index of economic freedom 2012-top 10 countries', http://www.heritage.org/ accessed 1 January 2013

Van Dai Tran, 2010, 'Exploring Construction Productivity Statistics in New Zealand', Master of Engineering Thesis, Auckland University of Technology, Auckland

Wang, Y.S. 1998, 'An Analysis of the Technical Efficiency in Hong Kong's Construction Industry', Unpublished PhD Thesis, University of Hong Kong, Hong Kong

Wang, Y.S. \& Chau, K.W. 1997, 'An evaluation of the technical efficiency of construction industry in Hong Kong using the DEA approach', Proceedings of ARCOM97 Conference, 690-701, Cambridge

Wang, Y.S. \& Chau, K.W. 2001, 'An assessment of the technical efficiency of construction firms in Hong Kong', International Journal of Construction Management, 29, 105-122

World Bank, 2011, 'Economy rankings - doing business'. http://www.doingbusiness.org/rankings accessed 1 January 2013

World Economic Forum, 2011, The Global Competitiveness Report 2011-2012, World Economic Forum, Geneva 